\title{
Exploring local adaptation and the ocean acidification seascape - studies in the California Current Large Marine Ecosystem
}

\author{
G. E. Hofmann ${ }^{1,3}$, T. G. Evans ${ }^{2}$, M. W. Kelly ${ }^{1, *}$, J. L. Padilla-Gamiño ${ }^{1}$, C. A. Blanchette ${ }^{3}$, L. Washburn ${ }^{3,4}$, F. Chan $^{5}$,

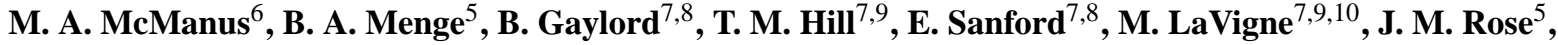 \\ L. Kapsenberg ${ }^{1}$, and J. M. Dutton ${ }^{1}$ \\ ${ }^{1}$ Department of Ecology, Evolution and Marine Biology, University of California Santa Barbara, Santa Barbara, CA \\ 93106-9620, USA \\ ${ }^{2}$ Department of Biological Sciences, California State University East Bay, Hayward, CA 94542, USA \\ ${ }^{3}$ Marine Science Institute, University of California Santa Barbara, Santa Barbara, CA 93106-6150, USA \\ ${ }^{4}$ Department of Geography, University of California Santa Barbara, Santa Barbara, CA 93106-4060, USA \\ ${ }^{5}$ Department of Zoology, Oregon State University, Corvallis, OR 97331-2914, USA \\ ${ }^{6}$ Department of Oceanography, University of Hawaii at Manoa, Honolulu, HI 96822, USA \\ ${ }^{7}$ Bodega Marine Laboratory, University of California Davis, Bodega Bay, CA 94923, USA \\ ${ }^{8}$ Department of Evolution and Ecology, University of California Davis, Davis, CA 95616, USA \\ ${ }^{9}$ Department of Geology, University of California Davis, Davis, CA 95616, USA \\ ${ }^{10}$ Department of Earth and Oceanographic Sciences, Bowdoin College, Brunswick, ME 04011, USA \\ * current address: Department of Biological Sciences, Louisiana State University, Baton Rouge, LA 70803, USA
}

Correspondence to: G. E. Hofmann (hofmann@lifesci.ucsb.edu)

Received: 31 March 2013 - Published in Biogeosciences Discuss.: 16 July 2013

Revised: 18 December 2013 - Accepted: 30 December 2013 - Published: 24 February 2014

\begin{abstract}
The California Current Large Marine Ecosystem (CCLME), a temperate marine region dominated by episodic upwelling, is predicted to experience rapid environmental change in the future due to ocean acidification. The aragonite saturation state within the California Current System is predicted to decrease in the future with near-permanent undersaturation conditions expected by the year 2050. Thus, the CCLME is a critical region to study due to the rapid rate of environmental change that resident organisms will experience and because of the economic and societal value of this coastal region. Recent efforts by a research consortium - the Ocean Margin Ecosystems Group for Acidification Studies (OMEGAS) - has begun to characterize a portion of the CCLME; both describing the spatial mosaic of $\mathrm{pH}$ in coastal waters and examining the responses of key calcification-dependent benthic marine organisms to natural variation in $\mathrm{pH}$ and to changes in carbonate chemistry that are expected in the coming decades. In this review, we present the OMEGAS strategy of co-locating sensors and oceanographic observations with biological studies on ben-
\end{abstract}

thic marine invertebrates, specifically measurements of functional traits such as calcification-related processes and genetic variation in populations that are locally adapted to conditions in a particular region of the coast. Highlighted in this contribution are (1) the OMEGAS sensor network that spans the west coast of the US from central Oregon to southern California, (2) initial findings of the carbonate chemistry amongst the OMEGAS study sites, and (3) an overview of the biological data that describes the acclimatization and the adaptation capacity of key benthic marine invertebrates within the CCLME.

\section{Introduction}

A leading imperative in global change biology is forecasting the impact of environmental change on key species and ecosystems (Buckley and Kingsolver, 2012; Hoffmann and Sgrò, 2011; Williams et al., 2008; Dawson et al., 2011), and on critical natural resources (Gillson et al., 2013; Ibáñez et 
al., 2013; Pettorelli, 2012). As exemplified by the study of ocean acidification (OA) (Boyd, 2011; Hofmann et al., 2011; Kroeker et al., 2013), the issues in this scientific endeavor are complex. In addition to the natural complexity in ecosystems emanating from biotic interactions and variability in biological responses to the environment, physical environmental parameters can also vary dramatically, as is evident when comparing disparate ecosystems such as tropical reefs and polar seas. From a biological perspective, one way to better predict the consequences of ocean change is to examine ways in which populations could potentially respond to environmental change. One mechanism is inherent physiological plasticity that confers tolerance to a changing environment (Chown, 2012; Chown and Gaston, 2008; Helmuth, 2009; Huey et al., 2012); a second is outright evolutionary adaptation to rapidly changing conditions (Hoffmann and Sgrò, 2011; Kelly and Hofmann, 2012; Visser, 2008; Sunday et al., 2013). Of the two responses, evolutionary adaptation may be the most difficult to study. The absence of extensive long-term data sets and the existence of complexity of biological processes combined with vast spatial expanses to cover have made studying evolution in the ocean a significant challenge.

In the oceans, major changes in temperature and carbonate chemistry are predicted in the coming decades (Feely et al., 2009; Gruber et al., 2012; Hauri et al., 2013; Orr et al., 2005) and in some ecosystems the rate of change will be rapid. For example, Australia is experiencing warming and extreme heat events (Wernberg et al., 2013) and the western Antarctic Peninsula has warmed significantly in the last two decades with significant decreases in sea ice that have already altered this polar marine ecosystem (Steinberg et al., 2012). In the California Current system, the focus of this article, aragonite saturation state in the upwelling zone is expected to decrease rapidly in the future (Gruber et al., 2012; Hauri et al., 2013). Here, within the next $30 \mathrm{yr}$, summer-long undersaturation conditions are expected in nearshore regions in the top $60 \mathrm{~m}$. Thus, the California Current Large Marine Ecosystem (CCLME) is a critical region to study, both in terms of the pace at which associated biota might experience rapid environmental change and because of the economic and societal value of this coastal region (Costanza et al., 1997). From a biological perspective, we have limited information on how critical species might respond to this predicted shift in ocean chemistry. Major questions remain regarding whether marine species currently possess functional traits that would allow the tolerance of a changing environment, or whether they will be able to adapt to rapidly changing ocean conditions into the future.

Recently, a collaborative group of investigators, who have been studying biological, ecological and oceanographic conditions along the US west coast for decades, has begun to tackle these questions in the CCLME using a strategy that involves co-locating oceanographic sensors with biological observations. This group, called OMEGAS (Ocean Margin Ecosystems Group for Acidification Studies), has worked as a collaborative body since 2010 studying an area spanning from central Oregon (OR) to southern California (CA; Fig. 1). Research activities include gathering oceanographic observations (e.g., $\mathrm{pH}, p \mathrm{CO}_{2}$, alkalinity, temperature, salinity, currents) that are matched with biological data (physiological measurements, organismal-level responses to low $\mathrm{pH}$ conditions such as growth rates and calcification, and genetic data) for key species of calcifying benthic marine invertebrates. The central goal of the OMEGAS project is to consider physiological and ecological performance of organisms, and genetic variation within and between populations, within the broad spatial mosaic of $\mathrm{pH}$ and saturation states found across the CCLME. Ocean acidification is driven by absorption of anthropogenic $\mathrm{CO}_{2}$ into surface waters and the commensurate change in ocean chemistry, both the reduction in $\mathrm{pH}$ and the decline in the concentration of carbonate ions, are physiologically challenging to calcifying marine organisms (Doney et al., 2009). Further, because $\mathrm{pH}$ and saturation state regimes vary widely across the CCLME, our research allows a "substitution of space for time" (Pickett, 1989) approach in an exploration of local adaptation of benthic marine invertebrates to carbonate chemistry (Sanford and Kelly, 2011). The combination of simultaneous oceanographic and biological research across a large latitudinal range will help identify areas on the coast that express a range of acidification conditions. This information may indicate areas that might be refuges from acidification in the future, and could reveal regions that are adaptation "hot spots"; i.e., places where selection for undersaturation-tolerant genotypes has been underway for long periods of time (Jacobs et al., 2004). Finally, discovery of tolerant populations within the environmental mosaic of the CCLME can provide an opportunity to identify mechanisms that underlie tolerance (Evans et al., 2013a; Evans and Hofmann, 2012). We also hope to address whether some species possess sufficient physiological and genetic variation to adapt to future change. Species that lack physiological plasticity may quickly become excluded from an environment when change occurs. Alternatively, organisms with the capacity to adapt should do so, and exploring the degree of standing genetic variation for $\mathrm{pH}$ tolerance may help us to forecast responses to environmental change (De Wit and Palumbi, 2012; Kelly et al., 2013; Pespeni et al., 2013a).

Thus, from a broad perspective, the OMEGAS strategy of co-locating sensors with biology allows one to explore the balance of physiological plasticity vs. capacity for adaptation in the light of present-day environmental conditions (Kelly and Hofmann, 2012). Such an assessment is critically important in allowing prediction of outcomes that rely on both species- and community-level responses (Kroeker et al., 2013; Wootton et al., 2008; Hall-Spencer et al., 2008). The goal of this article is to overview recent efforts of the OMEGAS consortium (http://omegas.science. oregonstate.edu) in the study of physiological plasticity and the capacity for adaptation in populations of benthic marine 


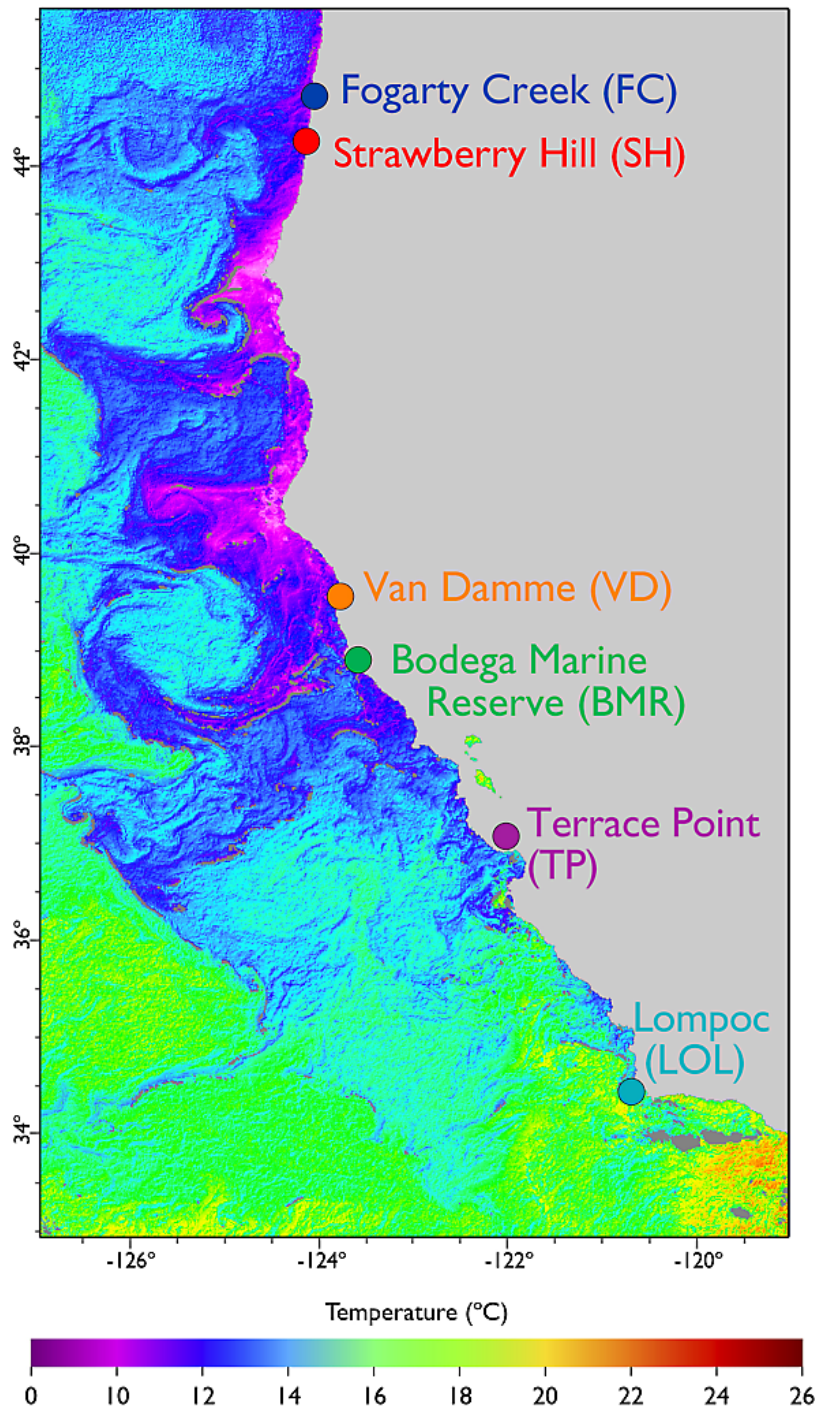

Fig. 1. Map of the OMEGAS study sites in the California Current Large Marine Ecosystem. The OMEGAS primary study sites are from north to south: Fogarty Creek (FC), Strawberry Hill (SH); Van Damme (VD); Bodega Marine Reserve (BMR); Terrace Point (TP) and Lompoc Landing (LOL). Note: colors in the image represent sea surface temperature $\left({ }^{\circ} \mathrm{C}\right)$ from the NOAA CoastWatch database.

invertebrates across the CCLME. Here, we outline three lines of investigation that are integrated across the group and that frame our studies: (1) an overview of a spatially distributed sensor network for quantifying $\mathrm{pH}$ dynamics, (2) data on functional traits that may vary in populations and support physiological plasticity, and (3) data on genetic structure of the study populations that link to local adaptation in natural populations and the capacity to adapt to future environmental change in the CCLME.

\section{The OMEGAS sensor network: identifying a pH mosaic in the CCLME}

A central goal of researchers within the OMEGAS consortium is to link biological performance with environmental variability in ocean carbonate chemistry along what we hypothesized would be a mosaic or gradient of conditions that might foster local adaptation. Long-term observations have been invaluable in defining the rate of OA progression in lowlatitude, open ocean biomes and records from sub-tropical gyre time-series stations (e.g., Bermuda Atlantic Time Series "BATS", http://www.bios.edu/research/bats.html; Hawaiian Ocean Times Series "HOT", http://hahana.soest.hawaii.edu/ hot/hot_jgofs.html; European Station for Time Series in the Ocean "ESTOC" http://www.eurosites.info/estoc.php) show a decline of ocean $\mathrm{pH}$ from -0.02 to $-0.04 \mathrm{pH}$ units over a $20 \mathrm{yr}$ period against low-frequency seasonal oscillations of similar magnitude (Bates et al., 2012; Dore et al., 2009; Santana-Casiano et al. 2007). For coastal regions, the scientific community is just now assessing the longer-term variability in $\mathrm{pH}$. Recent analyses of long-term data sets indicate that $\mathrm{pH}$ is changing rapidly in coastal Washington (Wootton and Pfister, 2012), in coastal upwelling zones along the US Pacific coast (Harris et al., 2013; Chan et al., 2014), at a coastal region in the Netherlands (Provoost et al., 2010), and in the Monterey Bay area where low pH water is associated with low oxygen water masses that reach the shallow, nearshore regions (Booth et al., 2012). Cruise data have provided snapshots of carbonate chemistry along the coast of the CCLME (Feely et al., 2008), and suggested that at some locations in northern California, undersaturated waters shoaled in the inner shelf. Prior to OMEGAS, however, no coordinated inner-shelf time series were available that would allow evaluation of the frequency, intensity and spatial expanse with which coastal ecosystems experience rapid acidification.

The recent development of autonomously recording $\mathrm{pH}$ sensors (Martz et al., 2010) has helped to bridge this data gap. Easily deployed on either moorings or benthic (e.g., rocky intertidal) locations, these sensors facilitate the collection of environmental $\mathrm{pH}$ data in a variety of habitats and support the collection of long-term data sets that more comprehensively characterize the OA seascape (Hofmann et al., 2013). Recent deployments of these sensors has highlighted that different ocean ecosystems display a great deal of natural variability in pH (Frieder et al., 2012; Hofmann et al., 2011; Kroeker et al., 2011; Price et al., 2012). Importantly, these sensors have created an affordable option for marine scientists to describe spatial patterns in ocean chemistry across dynamic coastal systems. In these environments, characterization of local-scale differences can be ecologically and economically critical, but require discrete sampling efforts that are often logistically and cost-prohibitive. Additionally, this strategy facilitates identification of refuges from future ocean acidification, information that would provide information to managers of coastal ecosystems and resources. It also allows the 
exploration of patterns of local adaptation to carbonate chemistry across large marine ecosystems such as the CCLME, where previous studies have demonstrated possible genetic differences among populations (De Wit and Palumbi, 2012; Kelly et al., 2013; Pespeni et al., 2012, 2013a, b, c).

In summer 2011, OMEGAS scientists deployed a network of environmental sensors on the US west coast at locations that span $\sim 1300 \mathrm{~km}$ of the CCLME. The sensor network included intertidally deployed instruments paired with instruments mounted on inner-shelf moorings (depth $=15-25 \mathrm{~m}$ ), initially at eight sites ranging from central Oregon to Santa Barbara, CA (Fig. 1). Descriptions of intertidal sensors and sites and mooring configurations can be found elsewhere (Washburn et al., 2011; Evans et al., 2013; Pespeni et al., 2013c; Adams et al., 2013), but briefly, $\mathrm{pH}$ records shown in Fig. 2 are from custom-designed Durafet ${ }^{\circledR}$-based sensors deployed in open coast, intertidal rocky habitats to record at $10 \mathrm{~min}$ intervals. Sensors were calibrated directly against certified reference materials (CRM) or indirectly against CRM-calibrated spectrophometric $\mathrm{pH}$ samples. Periodic (24 weeks) discrete samples were collected for checks on sensor performance in situ and for characterization of carbonate system chemistry via paired total alkalinity and total $\mathrm{CO}_{2}$ or total alkalinity and spectrophotometric $\mathrm{pH}$ samples. Information on the range of alkalinity in conjunction with the tight covariation between $\mathrm{pH}$ and $p \mathrm{CO}_{2}$ served to constrain the range of possible $p \mathrm{CO}_{2}$ values for the system and to inform treatment selection for laboratory studies. This region is well known for patterns of episodic upwelling that vary from relatively intermittent to the north and relatively persistent to the south (Checkley Jr and Barth, 2009; Menge and Menge, 2013). Recent efforts to characterize the nearshore carbonate chemistry of the California Current system (Fassbender et al., 2011; Feely et al., 2008; Hauri et al., 2009) suggest that biota of this region experience natural variation in $\mathrm{pH}$ due to latitudinally and temporally variable upwelling. Results from the OMEGAS sensor network indicate that acidification of coastal waters extends into the nearshore environments of the CCLME with low $\mathrm{pH}$, undersaturated water reaching the rocky intertidal zone (Evans et al., 2013; Pespeni et al., 2013c; Chan et al., 2014). Importantly, these data indicate that biota in the plankton and benthic marine organisms on shore face an exposure regime to low $\mathrm{pH}$ and undersaturated waters that is tremendously dynamic in time and space (Evans et al., 2013; Chan et al., 2014). Across the OMEGAS network, the frequency of low $\mathrm{pH}$ events encountered in intertidal sensors ranged widely (Fig. 2). In central Oregon, as much as $20 \%$ of $\mathrm{pH}$ values fell below 7.8. In contrast, sites in central and southern California experienced exposure to $\mathrm{pH}$ values below 7.8 less than $2 \%$ of the time. This pattern of spatial separation is even more pronounced when we consider $\mathrm{pH}$ exposure at even lower-thresholds. For example, the frequency of exposure to low $\mathrm{pH}$ conditions of 7.7 or less at Bodega Marine Reserve (BMR) - a site in the geographic center of the network - is most similar to a station $700 \mathrm{~km}$
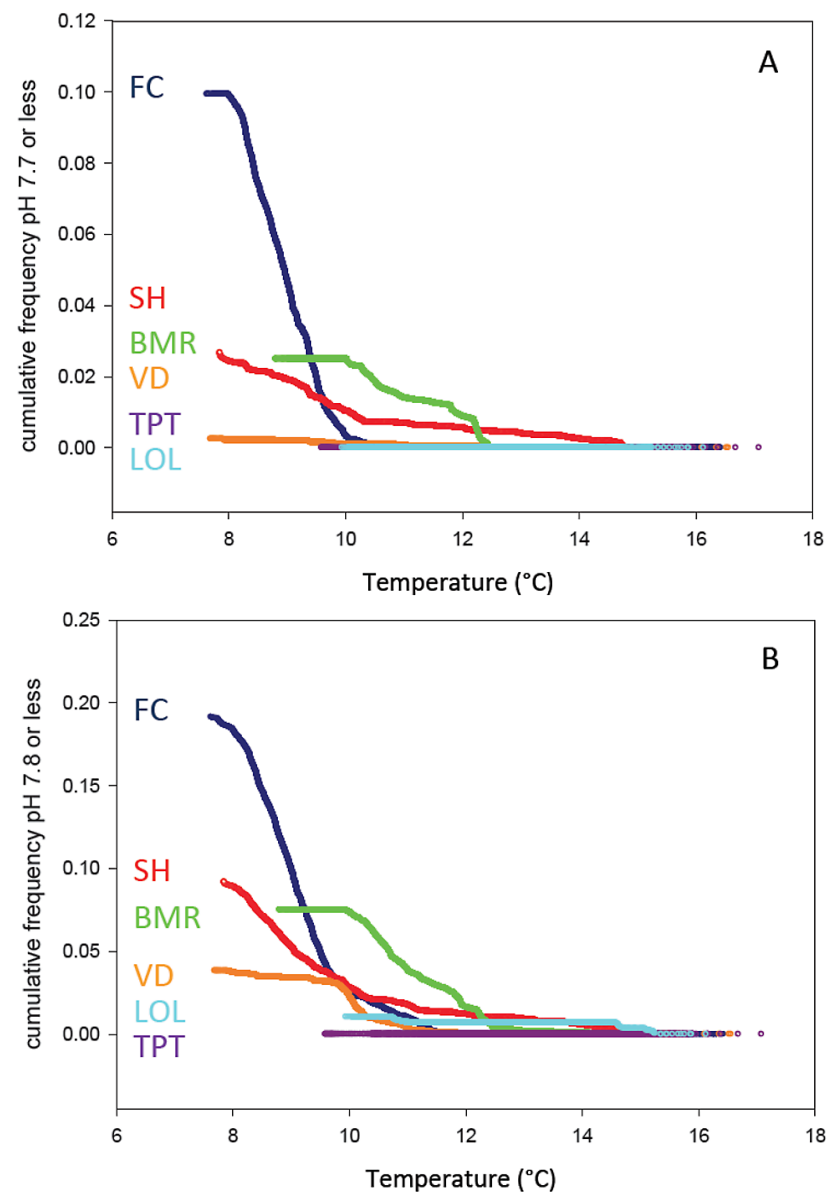

Fig. 2. Cumulative frequencies of exposure to $\mathrm{pH}$ (total scale) less than 7.7 (A) and 7.8 (B) as recorded at $10 \mathrm{~min}$ intervals by in situ Durafet ${ }^{\circledR}$-based pH sensors deployed in intertidal environment between April and September (maximum record length). Exposure frequencies at a given $\mathrm{pH}$ threshold are normalized to expanding windows of maximum to minimum in situ water temperature to illustrate the response of $\mathrm{pH}$ to the progressive strengthening of seasonal upwelling at each site.

to the north in central Oregon at Strawberry Hill (SH), than adjacent stations within $150 \mathrm{~km}$ to the north at Van Damme (VD) and the southern site Terrace Point (TP). At $14^{\circ} \mathrm{C}$, this $\mathrm{pH}$ corresponds to a $p \mathrm{CO}_{2}$ value of $1200 \mu$ atm in our system. Such values were used to inform experiments described below (Fig. 3). Our emerging understanding from this first year of operational deployment of the OMEGAS network thus suggests a mosaic-like coastal $\mathrm{pH}$ seascape where organism's exposure to $\mathrm{OA}$ is both geographically defined and variable over spatial scales of dispersal of marine larvae (Gouhier et al., 2010; Navarrete et al., 2008).

Further, analysis of the time series data show that there is a mosaic of OA where sites in the northern portion of the study region (in central Oregon) have a greater intensity of exposure to low $\mathrm{pH}$ than sites in the southern portion of the study region (Fig. 2). Specifically, when parsing the data as 


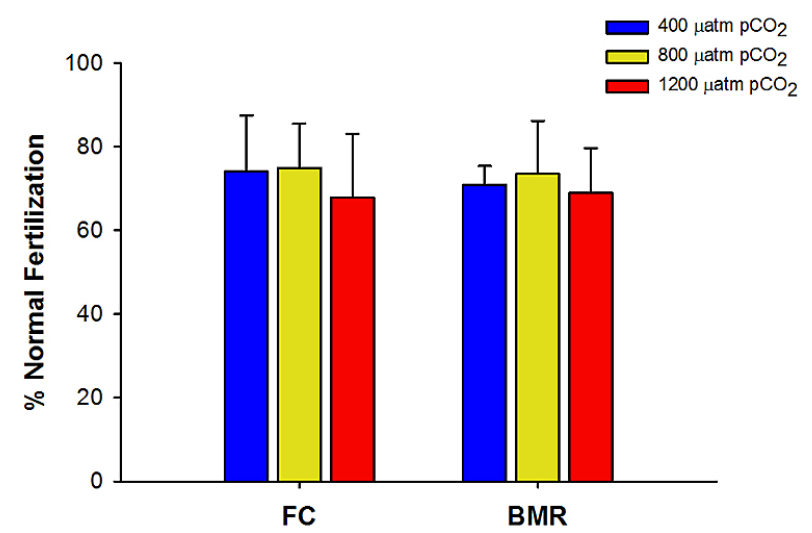

Fig. 3. Fertilization success of Strongylocentrotus purpuratus gametes across populations and $p \mathrm{CO}_{2}$ treatments. Adult urchins were collected from two locations that spanned the CCLME and the OMEGAS study sites: Fogarty Creek (FC), OR, and Bodega Marine Reserve (BMR), CA. Adult pairs from the same site were spawned in the laboratory (FC $N=12$ pairs; BMR $N=8$ pairs). Eggs were fertilized at $14{ }^{\circ} \mathrm{C}$ under control (400 $\left.\mu \mathrm{atm}\right)$ and elevated $(800 \mu \mathrm{atm}$, $1200 \mu \mathrm{atm}) ~ p \mathrm{CO}_{2}$ conditions at an ecologically relevant sperm concentration of $7 \times 10^{3}$ sperm $\mathrm{mL}^{-1}$. Gametes were allowed a $30 \mathrm{~min}$ contact time and at least 200 eggs were scored per pair after the second cleavage. There was no significant effect of $p \mathrm{CO}_{2}$ by population (two-way ANOVA; $p \mathrm{CO}_{2} \times$ site effect $p=0.8577 ; p \mathrm{CO}_{2}$ effect $p=0.3168$; site effect $p=0.7147$ ). A similar pattern was observed at higher and lower sperm concentrations (data not shown).

a function of measurements below pH 7.7, Fogarty Creek (FC) in Oregon has a much greater number of measurements below pH 7.7 whereas sites in California, Lompoc Landing (LOL), have the lowest frequency (Fig. 2a). If that filter is changed to $\mathrm{pH} 7.8$, Fogarty Creek continues to maintain its position as the site with the greatest frequency of low $\mathrm{pH}$ exposure, other sites in central California begin to show elevated frequency of low $\mathrm{pH}$ but LOL in the south persists in being a low OA site (Fig. 2b).

\section{The biology: assessing physiological plasticity and functional traits}

Having demonstrated the mosaic of $\mathrm{pH}$ experienced by organisms at study sites across the CCLME, OMEGAS investigators began to explore whether there are functional traits and physiological performance profiles in key calcificationdependent organisms that are acclimatized to this pattern of carbonate chemistry conditions. Although it is difficult to pin any one phenotypic element on a single selection factor in the environment (e.g., temperature or $\mathrm{pH}$ alone), the importance of the phenotype and tolerance traits has been increasingly recognized as a key mechanism by which a species might respond to environmental change in a number of systems (Buckley and Kingsolver, 2012; Chown, 2012; Chown and Gaston, 2008; Helmuth, 2009). Recently within the
OMEGAS research community, functional traits and physiological tolerances have been measured in an environmentally relevant context (Evans et al., 2013; Kelly et al., 2013; Padilla-Gamiño et al., 2013; Pespeni et al., 2013a; Yu et al., 2011). The OMEGAS group hypothesized that such phenotypic traits would show variation across space if benthic invertebrates are acclimatized to the local conditions (Chown, 2012) such that they might also contribute to how species respond to environmental change.

Studies initiated by the OMEGAS research teams first focused on populations of ecologically important calcificationdependent benthic marine invertebrates, the purple sea urchin, Strongylocentrotus purpuratus, and the mussel, Mytilus californianus, across the OMEGAS study sites. Experiments conducted by the group included field experiments at different OMEGAS sites and laboratory mesocosms that tested the response of organisms from various populations to variation in $\mathrm{pH}$. The overall results of the laboratory component demonstrated that the two study organisms displayed different degrees of sensitivity to shifts in ocean chemistry with sea urchins appearing to be more resilient to variation in partial pressure of carbon dioxide $\left(p \mathrm{CO}_{2}\right)$ than mussels. Specifically, larval culturing of purple sea urchins in $\mathrm{CO}_{2}$ mesocosms showed sea urchin larvae were tolerant of $p \mathrm{CO}_{2}$ levels that are representative of present-day $p \mathrm{CO}_{2}$ levels documented by OMEGAS field sensors. That is, growth, morphology, early development to echinopluteus and development to metamorphosis were rarely affected (Kelly et al., 2013; Padilla-Gamiño et al., 2013; Pespeni et al., 2013a), although minor decreases in the size of the larval skeleton were seen at elevated $p \mathrm{CO}_{2}$ s of around $1000 \mu \mathrm{atm}$ (PadillaGamiño et al., 2013). The mechanistic underpinning of this tolerance and physiological plasticity is currently being examined in greater detail. However, in the analyses of urchin larvae from the $\mathrm{CO}_{2}$ mesocosm experiments, the transcriptome displayed variable gene expression during development that likely compensates for carbonate under-saturation and challenges to calcification and $\mathrm{pH}_{i}$ homeostasis (Evans et al., 2013a). In contrast, laboratory studies on mussel larvae (M. californianus) showed that low $\mathrm{pH}$ conditions reduced growth and shell strength (Gaylord et al., 2011). In light of the $\mathrm{pH}$ mosaic data from the sensors, these results suggest that mussel recruits will vary across the CCLME in terms of their susceptibility to drilling and crushing predators, and that susceptibility will increase through time.

When functional traits were compared from animals in populations across the OMEGAS study sites, we found a more complicated story. However, for the most part, results thus far highlight a resilience of function in the study's marine invertebrate organisms. First, in line with the robustness of the early-life embryonic stages of sea urchins in mesocosm studies, analysis of fertilization kinetics using adult, purple sea urchins collected from OMEGAS sites showed that fertilization success was not affected by elevated $p \mathrm{CO}_{2}$ (Fig. 3), with populations from both FC and further south 
at BMR showing the same insensitivity to elevated $p \mathrm{CO}_{2}$. Similarly, larval culturing of sea urchins demonstrated that larvae from northern and southern populations have similar and more resilient metabolic responses to $p \mathrm{CO}_{2}$ (Kelly et al., 2013). Specifically, oxygen consumption rates in early pluteus did not change between larvae reared under different $p \mathrm{CO}_{2}$ conditions (Fig. $4 \mathrm{a}$ ), and this response was consistent between populations exposed to different upwelling regimes (Kelly et al., 2013). Examining a feature of juvenile and adult sea urchins - the mineralogy of the calcium carbonate skeleton- LaVigne et al. (2013) found that for the most part the composition of the skeleton was not different in urchins collected across the latitudinal gradient of the OMEGAS study sites. Adult spine composition $(\mathrm{Mg} / \mathrm{Ca}$ and $\mathrm{Sr} / \mathrm{Ca}$ ratios) was not different between populations from Fogarty Creek, Oregon, in the north to others near Lompoc Landing in southern California (LaVigne et al., 2013) (Fig. 4b).

Finally, field experiments examined mussel growth at all the OMEGAS sites and, surprisingly, evidence to date suggests that adult mussel growth was not reduced at low $\mathrm{pH}$ sites across the OMEGAS regions (Fig. 4c). The results are more strongly correlated to other characteristics of the sites and growth may be driven by other factors such as food availability (Thomsen et al., 2013) and temperature (Blanchette et al., 2007; Menge et al., 2008). These results that highlight different responses in life history stages of mussels (adult vs. larval forms) are intriguing, and our emphasis in future research will be to investigate the changes in physiology and ecology that underlie this apparent ontogenetic shift in sensitivity in $M$. californianus.

Taken together, studies initiated by the OMEGAS research teams have made two critical observations: species display a range of sensitivities to OA in the laboratory, and patterns of functional traits in natural populations show unexpected divergences from expectations (e.g., faster growth at sites with more extreme exposure to $\mathrm{pH}$ ). Additional insights and resolution of these patterns await further study in the coming field seasons for OMEGAS research. Finally, it should be noted that only a very few species from the rich biota of the CCLME have been studied in an OA context (Table 1) and determining the OA tolerance across a larger number of species occupying similar $\mathrm{pH}$ environments in the CCLME is a critical research need.

\section{Local adaptation and benthic marine invertebrates of the CCLME}

In addition to studying functional traits of study organisms, several lines of investigation within the OMEGAS group have been designed to address local adaptation. Local adaptation occurs when there is genetic variation among populations that matches some aspect of the environment, so that on average "local" genotypes outperform "foreign" genotypes when they compete against one another in the home environment (Kawecki and Ebert, 2004). An understanding of local adaptation is relevant to forecasting a species' capacity to adapt to global change for two reasons. First, adaptation depends on genetic variation. Local adaptation to a particular gradient (temperature, $\mathrm{pH}$ ) implies the existence of variation that will allow for adaptation to changes in that gradient in the future. In addition, the capacity to adapt to an environmental variable in space, suggests the capacity to adapt to changes in that variable through time. And conversely, limits to adaptation in space (for example failure to adapt to maximum temperatures above $20^{\circ} \mathrm{C}$ at a southern range limit) suggest possible limits to adaptation in the face of future changes.

There are several approaches to describing local adaptation. The gold standard for demonstrating local adaptation is a set of reciprocal transplants among sites, followed by a comparison of some aspect of performance for "local" vs. "foreign" genotypes in each environment. However, when local genotypes can be shown to have the highest performance in a particular environment it will not always be clear to which aspect of the environment they are responding to, as aspects of the environment (e.g., temperature, $\mathrm{pH}$, biotic interactions) often co-vary. To test for adaptation to a specific environmental variable of interest, it will often be necessary to bring organisms from different populations into the laboratory, and examine variation in performance along a particular axis of environmental variation.

This type of laboratory experiment was done by OMEGAS investigators with sea urchins. Kelly et al. (2013) performed quantitative genetic crosses among purple sea urchins (Strongylocentrotus purpuratus) from two different sites with different upwelling regimes, and then reared the offspring of these crosses under high and low $p \mathrm{CO}_{2}$. They found abundant genetic variation for the response to high $p \mathrm{CO}_{2}$, but only minor differences between the offspring of males from the two sites. However these small differences were consistent with local adaptation to $\mathrm{pH}$, with offspring from the site with more exposure to extreme $\mathrm{pH}$ levels showing a lesser sensitivity to low $\mathrm{pH}$ (Fig. 5). The lack of large differences among populations is also consistent with the biology of purple urchins, which have long-lived planktonic larvae, and therefore relatively homogenized populations (Edmands et al., 1996).

Another way to demonstrate genetic differences among populations is to identify differences in actual gene sequences. Pespeni et al. (2012) performed a genome-wide scan of polymorphisms for two distant populations of the purple urchin $S$. purpuratus. They found many polymorphisms whose frequencies differed strongly among populations, indicating that they were targets of selective forces that differed among these populations. Similarly, De Wit and Palumbi (2013) used transcriptome sequencing of three populations of the red abalone (Haliotis rufescens) to identify single nucleotide polymorphisms (SNPS) in genes that 
Table 1. Ocean acidification studies on functional traits of organisms in the California Current Large Marine Ecosystem.

\begin{tabular}{|c|c|c|c|c|c|}
\hline $\begin{array}{l}\text { Taxonomic } \\
\text { Group }\end{array}$ & Species Name & $\begin{array}{l}\text { Life } \\
\text { Stage }\end{array}$ & $\begin{array}{l}\text { Variable } \\
\text { Measured }\end{array}$ & Response & Source \\
\hline Invertebrate & $\begin{array}{l}\text { Strongylocentrotus } \\
\text { franciscanus }\end{array}$ & Larvae & $\begin{array}{l}\text { Transcription of } \\
h s p 70\end{array}$ & $\begin{array}{l}\text { Larvae that were raised under enhanced } \\
\mathrm{CO}_{2} \text { displayed compromised expression of } \\
\text { the thermally induced molecular chaperone } \\
\text { hsp } 70 .\end{array}$ & O’Donnell et al. (2009) \\
\hline Invertebrate & Lytechinus pictus & Larvae & $\begin{array}{l}\text { Morphometrics } \\
\text { transcriptomics }\end{array}$ & $\begin{array}{l}\text { Larvae cultured under high } \mathrm{CO}_{2} \text { were } \\
\text { smaller and had a more triangular body. } \\
\text { Downregulation of genes related to } \\
\text { metabolism and biomineralization. Up- } \\
\text { regulation of a few genes related to ion } \\
\text { regulation and acid-base pathways. }\end{array}$ & O’Donnell et al. (2010) \\
\hline Invertebrate & Mytilus californianus & Larvae & $\begin{array}{l}\text { Shell strength } \\
\text { and size }\end{array}$ & $\begin{array}{l}\text { Larvae raised under high } \mathrm{CO}_{2} \text { developed } \\
\text { thinner, weaker and smaller shells as com- } \\
\text { pared to controls. }\end{array}$ & Gaylord et al. (2011) \\
\hline Invertebrate & $\begin{array}{l}\text { Mytilus trossulus and } \\
\text { Strongylocentrotus } \\
\text { franciscanus }\end{array}$ & Larvae & Developmental rate & $\begin{array}{l}\text { Decrease in larval body size in both the sea } \\
\text { urchin and the mussel. }\end{array}$ & Sunday et al. (2011) \\
\hline Invertebrate & $\begin{array}{l}\text { Haliotis } \\
\text { kamtschatkana }\end{array}$ & Larvae & $\begin{array}{l}\text { Development, size } \\
\text { and survivorship }\end{array}$ & $\begin{array}{l}\text { Exposure to high } \mathrm{CO}_{2} \text { during development } \\
\text { resulted in lower survival, abnormal devel- } \\
\text { opment and smaller size in the northern } \\
\text { abalone. }\end{array}$ & Crim et al. (2011) \\
\hline Invertebrate & $\begin{array}{l}\text { Strongylocentrotus } \\
\text { purpuratus }\end{array}$ & Larvae & Development size & $\begin{array}{l}\text { No differences in development between low } \\
\text { and high } \mathrm{CO}_{2} \text { treatments. Smaller larvae in } \\
\text { the high } \mathrm{CO}_{2} \text { treatment. }\end{array}$ & Yu et al. (2011) \\
\hline Microbes & Nitrifiers & $\mathrm{n} / \mathrm{a}$ & $\begin{array}{l}\text { Ammonia oxidation } \\
\text { rates }\end{array}$ & $\begin{array}{l}\text { Microbial nitrification rates decreased when } \\
\mathrm{pH} \text { was experimentally reduced. }\end{array}$ & Beman et al. (2011) \\
\hline Invertebrate & Ostreola conchaphila & $\begin{array}{l}\text { Larvae } \\
\text { Juvenile }\end{array}$ & $\begin{array}{l}\text { Shell growth rate, } \\
\text { shell area }\end{array}$ & $\begin{array}{l}\text { Carryover effects of water chemistry ex- } \\
\text { perienced at early stage (larvae) to the } \\
\text { later post-larval juvenile stage. Juveniles } \\
\text { exposed to acidified conditions in their lar- } \\
\text { val stages failed to attain the same size as } \\
\text { juveniles derived from larvae exposed to } \\
\text { less acidic conditions. }\end{array}$ & Hettinger et al. (2012) \\
\hline Algae & $\begin{array}{l}\text { Pseudo-nitzschia } \\
\text { fraudulenta }\end{array}$ & $\mathrm{n} / \mathrm{a}$ & $\begin{array}{l}\text { Domoic acid pro- } \\
\text { duction, cellular } \\
\mathrm{Si}: \mathrm{C} \text { ratios }\end{array}$ & $\begin{array}{l}\text { Strong synergism between high } \mathrm{CO}_{2} \text { levels } \\
\text { and silicate-limited growth, which greatly } \\
\text { increases cellular toxicity relative to growth } \\
\text { under lower } \mathrm{CO}_{2} \text { conditions. }\end{array}$ & Tatters et al. (2012) \\
\hline Invertebrate & $\begin{array}{l}\text { Strongylocentrotus } \\
\text { purpuratus }\end{array}$ & $\begin{array}{l}\text { Juvenile } \\
\text { Adults }\end{array}$ & $\mathrm{Mg} / \mathrm{Ca}, \mathrm{Sr} / \mathrm{Ca}$ & $\begin{array}{l}\text { Composition of skeleton precipitated dur- } \\
\text { ing early and adult life history stages ap- } \\
\text { pears relatively robust to spatial gradients } \\
\text { and predicted changes in seawater chem- } \\
\text { istry. }\end{array}$ & LaVigne et al. (2012) \\
\hline Invertebrate & $\begin{array}{l}\text { Strongylocentrotus } \\
\text { purpuratus }\end{array}$ & Larvae & $\begin{array}{l}\text { Morphometrics and } \\
\text { biochemical } \\
\text { responses }\end{array}$ & $\begin{array}{l}\text { Lipid utilization rates and protein content } \\
\text { did not vary with } p \mathrm{CO}_{2} \text {, larval growth was } \\
\text { reduced at elevated } p \mathrm{CO}_{2} \text { despite similar } \\
\text { rates of energy utilization, and relationships } \\
\text { between egg phospholipid content and lar- } \\
\text { val length were found under control but not } \\
\text { high } p \mathrm{CO}_{2} \text { conditions. }\end{array}$ & Matson et al. (2012) \\
\hline Invertebrate & $\begin{array}{l}\text { Strongylocentrotus } \\
\text { purpuratus }\end{array}$ & Larvae & Transcriptomics & $\begin{array}{l}\text { Upregulation of several calcium trans- } \\
\text { porters and binding proteins in a population } \\
\text { of urchins from an intertidal site character- } \\
\text { ized by low and fluctuating pH. }\end{array}$ & Evans et al. (2013a) \\
\hline Invertebrate & $\begin{array}{l}\text { Strongylocentrotus } \\
\text { purpuratus }\end{array}$ & Larvae & $\begin{array}{l}\text { Development, size, } \\
\text { respiration, } \\
\text { transcriptomics }\end{array}$ & $\begin{array}{l}\text { Additive effects of high temperature and } \\
\text { high } \mathrm{CO}_{2} \text { conditions induce metabolic de- } \\
\text { pression and a major downregulation of hi- } \\
\text { stone encoding genes. No differences in de- } \\
\text { velopment between } \mathrm{CO}_{2} \text { treatments were } \\
\text { found. }\end{array}$ & Padilla-Gamiño et al. (2013) \\
\hline Invertebrate & $\begin{array}{l}\text { Strongylocentrotus } \\
\text { purpuratus }\end{array}$ & Larvae & $\begin{array}{l}\text { Heritability, } \\
\text { genetic variation, } \\
\text { size }\end{array}$ & $\begin{array}{l}\text { Genetic variation in the response to ocean } \\
\text { acidification, indicating potential for adap- } \\
\text { tation. Smaller larvae under high } \mathrm{CO}_{2} \text { con- } \\
\text { ditions. }\end{array}$ & Kelly et al. (2013) \\
\hline Invertebrate & Mytilus trossulus & Adults & $\begin{array}{l}\text { Strength of byssal } \\
\text { threads }\end{array}$ & $\begin{array}{l}\text { Threads grown under high } p \mathrm{CO}_{2} \text { condi- } \\
\text { tions exhibited compromised mechanical } \\
\text { characteristics. }\end{array}$ & O’Donnell et al. (2013) \\
\hline
\end{tabular}


A. Respiration in larval urchins
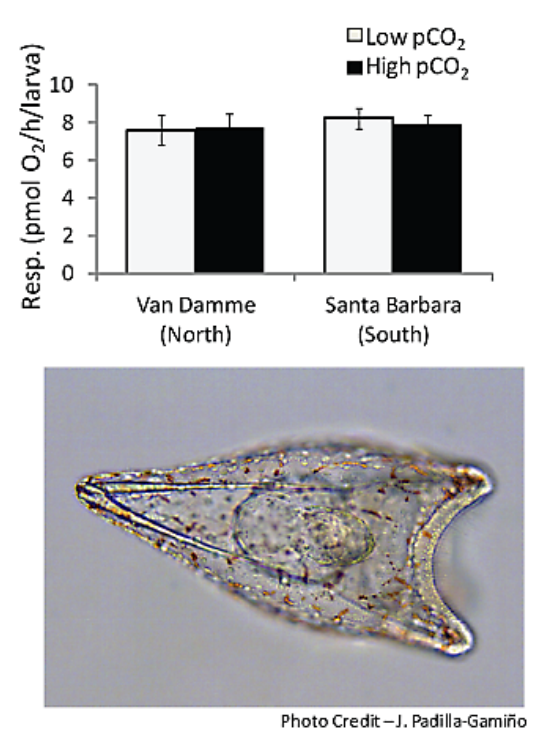

B. $\mathrm{Mg} / \mathrm{Ca}$ and $\mathrm{Sr} / \mathrm{Ca}$ in urchins
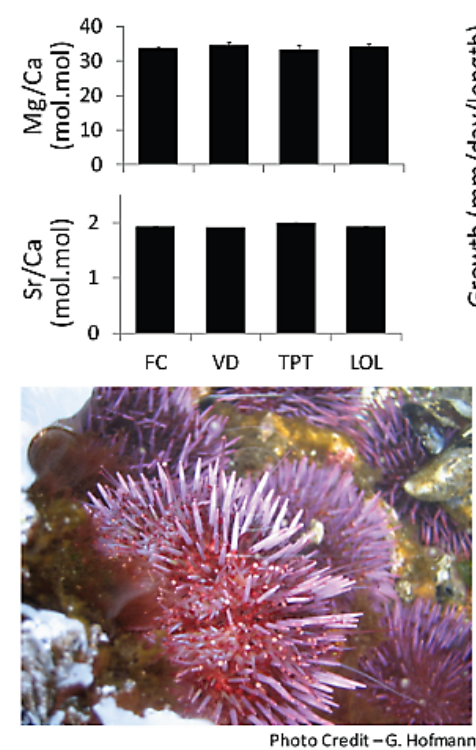

\section{Growth in intertidal mussels}
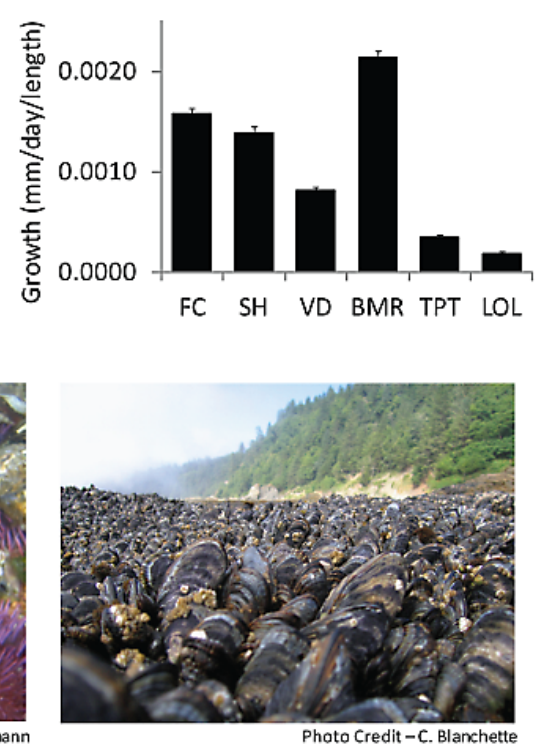

Fig. 4. Responses of marine calcifiers at the OMEGAS sites. (A) Respiration rates in larval sea urchins of Strongylocentrotus purpuratus; Sea urchin larvae from the Santa Barbara area and Van Damme were raised at $13{ }^{\circ} \mathrm{C}$ under high $(1100 \mu$ atm $)$ and low $(400 \mu$ atm $) p \mathrm{CO}_{2}$ using a flow-through $\mathrm{CO}_{2}$ mixing system. Rates of oxygen consumption were obtained $92 \mathrm{~h}$ after fertilization in early pluteus larvae. Larval respiratory rates did not differ among sites or $p \mathrm{CO}_{2}$ treatments. (B) Biomineral composition of the spines of adult $S$. purpuratus; data shown are mean $\mathrm{Mg} / \mathrm{Ca}$ (upper panel) and $\mathrm{Sr} / \mathrm{Ca}$ (lower panel) ratios for spines collected from adult urchins at OMEGAS study sites: Purisma Point (PP), CA, near Lompoc Landing, Terrace Point (TPT), CA, Van Damme State Park (VD) and Fogarty Creek (FC), OR; (C) Growth of intertidal mussels, Mytilus californianus, during the 2011 summer upwelling season. Mussels $\sim 40 \mathrm{~mm}$ in length were collected in April 2011 from the OMEGAS sites, notched at the posterior lip of the shell, and outplanted back to each site. Mussels were retrieved in October 2011, and growth was measured as the increase in shell length. Growth rate is expressed as millimeters per day, standardized by initial length; results shown here are scaled by the number of days for the study duration at each site and the individual mussel length at study initiation. Site abbreviations as in Fig. 1 and the text.

appeared to be under spatially varying selection. A limitation of the approach used in both of these studies is that variation in gene sequences often cannot be directly tied to variation in organismal performance. Furthermore, because of co-variation in environmental variables it is often difficult to know which aspect of the environment is selecting for differences in allele frequencies among populations. However studies like these provide a rich foundation for ongoing work attempting to identify the genetic basis of local adaptation. Notably, in a mesocosm experiment where urchin larvae from OMEGAS study sites were cultured under ecologically relevant $p \mathrm{CO}_{2}$ conditions for the CCLME, Pespeni et al. (2013a) found significant allelic change in 40 classes of functional proteins in gene classes for ion homeostasis and biomineralization, suggesting that standing genetic variation does exist within these study populations at the OMEGAS sites.

We are currently testing for local adaptation to carbonate chemistry in another species from the CCLME with a very different life history and dispersal mode from purple urchins. Coralline algae are an ecologically important group of marine calcifiers that live in almost every habitat in the world's oceans, from the tropics to the polar regions (Johansen, 1981). Coralline algae are very abundant along the CCLME (Abbott and Hollenberg, 1976) providing substrata and settlement cues to invertebrate larvae and serving as habitat for many marine species (Johansen, 1981). Coralline algae are highly vulnerable to ocean acidification (Koch et al., 2013) and, to date, it is unclear how more acidified waters will affect algal physiological mechanisms dependent on $\mathrm{HCO}_{3}$ and $\mathrm{CO}_{3}^{2-}$ availability such as photosynthesis and calcification. Coralline algae reproduce by releasing spores (Johansen, 1981) that can fully attach to the bottom within hours of release (Miklasz, 2012) and recruit near the parental alga. This feature of coralline algae life history could limit dispersal distance and increase the potential for local adaptation in this group. We are currently examining how ocean acidification can affect the growth of spores from the articulated coralline algae Corallina vancouveriensis, which is an abundant species in the intertidal zone within the CCLME (Abbott and Hollenberg, 1976). Using populations exposed to different oceanographic conditions we are examining whether there is genetic variation among individuals and how this genetic variation is distributed among populations. Differences 

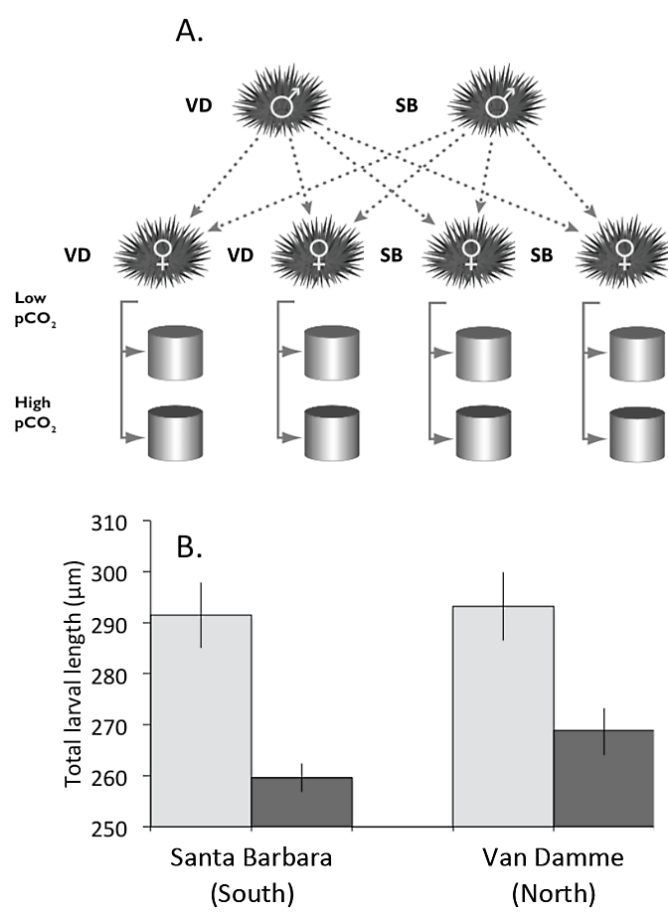

Fig. 5. Breeding experiment conducted using purple urchin adults collected from two OMEGAS study sites. (A) Cross design: we crossed adult urchins from two sites in California, US (inset), known to differ in their carbonate chemistry regimes (OMEGAS sites: northern CA, Van Damme; southern CA, Santa Barbara). In the lab, we crossed each male with two females from his own site, and two females from the opposite site, and split embryos from each cross into low and high $p \mathrm{CO}_{2}$ rearing conditions. (B) Total larval length $( \pm \mathrm{SD})$ of $S$. purpuratus raised for five days under low $p \mathrm{CO}_{2}$ and high $p \mathrm{CO}_{2}$ conditions. Offspring of northern CA sires are larger than the offspring of southern CA sires under high $p \mathrm{CO}_{2}(\mathrm{pMCMC}=0.012)$ but not under low $p \mathrm{CO}_{2}(\mathrm{pM}-$ $\mathrm{CMC}=0.27$ ). Modified from Kelly et al 2013 .

in the potential for adaptation could have important implications for the distribution of $C$. vancouveriensis and the organisms in the CCLME that depend on them.

\section{Summary and future directions}

The OMEGAS consortium has used a strategy of co-locating sensors and biological observations to begin to describe patterns of acclimatization and local adaptation in the CCLME. Ultimately, the goal of this research consortium is to use this information to forecast the impacts of future acidification in coastal regions around the globe. Co-locating sensors with measures of physiological performance makes sense, but should be more deeply appreciated in a biological context. Since it is the physical environment that makes a large contribution to genetic variation in populations, we would predict that regions characterized by large variation in $\mathrm{pH}$ and changes in saturation state may have organisms with different physiological tolerances and with different genetics in terms of OA tolerance (Kelly and Hofmann, 2012; Kelly et al., 2013; Pespeni et al., 2013a). Thus, from a global change biology perspective, this strategy also allows us to explore the extent to which physiological plasticity vs. the capacity for adaptation might play a role in species response to environmental change.

Our emerging understanding of a spatial mosaic of coastal $\mathrm{pH}$ has facilitated studies of biological responses to systemrelevant, mean-state changes in carbonate chemistry. As we gain insights from this first-order coupling between field observations and laboratory studies, we anticipate that a deepening understanding of the temporal variability of OA stress, its scope for future changes and covariation with other global change stressors will similarly enable a new generation of physiological, ecological and evolutionary studies. For example, organisms in the CCLME will face changes in exposures to both the severity and frequency of low $\mathrm{pH}$ and saturation state conditions (Hauri et al., 2013), with impacts that can interact with exposures to declining oxygen concentrations (Rykaczewski and Dunne 2010, Cocco et al., 2012). While capacity for resolving mean state vs. variability impacts and interactions between multiple stressors remains a limiting factor in the field, development of new experimental systems (Bockmon et al., 2013) can enable experimental treatments that mimic exposure regimes that organisms are observed and forecasted to face in situ. Such advances will be crucial to making more robust forecasts regarding the ecological consequences of future ocean change (Boyd, 2011; Harvey et al., 2013). Finally, as the complexity of this issue unfolds it will require that scientists engage more actively with policy makers, conservation biologists, and managers of critical marine ecosystems (Dawson et al., 2011; Ibáñez et al., 2013; Kelly et al., 2011).

Acknowledgements. We thank NOAA CoastWatch and Reiko Michisaki for providing the satellite image used in Fig. 1. This research was funded by US National Science Foundation grant (NSF OCE-1040960) to the Ocean Margins Ecosystem Group for Acidification Studies (OMEGAS), a consortium of scientists from different institutions along the US west coast (see http://omegas.science.oregonstate.edu/), by funds from NSF grant IOS-1021536 to G. E. Hofmann and by funds from the University of California in support of a multi-campus research program, Ocean Acidification: A Training and Research Consortium (http://oceanacidification.msi.ucsb.edu/), to G. E. Hofmann, E. Sanford, B. Gaylord, and T. M Hill. Research presented here was also supported in part by grants from the David and Lucile Packard Foundation to the Partnership for Interdisciplinary Studies of Coastal Oceans (PISCO) consortium (http://piscoweb.org).

Edited by: R. Feely 


\section{References}

Abbott, I. A. and Hollenberg, G. J.: Marine algae of california, 1st ed., Stanford University Press, 827 pp., 1976.

Adams, K. A., Chan, F., and Barth, J. A.: Temporal variability of near-bottom dissolved oxygen during upwelling off central Oregon, J. Geophys. Res.-Oceans, 118, 4839-4854, 2013.

Bates, N. R., Best, M. H. P., Neely, K., Garley, R., Dickson, A. G., and Johnson, R. J.: Detecting anthropogenic carbon dioxide uptake and ocean acidification in the North Atlantic Ocean, Biogeosciences, 9, 2509-2522, doi:10.5194/bg-9-2509-2012, 2012.

Beman, J. M., Chow, C. E., King, A. L., Feng, Y. Y., Fuhrman, J. A., Andersson, A., Bates, N. R., Popp, B. N., and Hutchins, D. A.: Global declines in oceanic nitrification rates as a consequence of ocean acidification, P. Natl. Acad. Sci. USA, 108, 208-213, doi:10.1073/pnas.1011053108, 2011.

Blanchette, C. A., Helmuth, B., and Gaines, S. D.: Spatial patterns of growth in the mussel, Mytilus californianus, across a major oceanographic and biogeographic boundary at Point Conception, California, USA, J. Exp. Mar. Biol. Ecol., 340, 126-148, doi:10.1016/j.jembe.2006.09.022, 2007.

Bockmon, E. E., Frieder, C. A., Navarro, M. O., White-Kershek, L. A., and Dickson, A. G.: Technical Note: Controlled experimental aquarium system for multi-stressor investigation of carbonate chemistry, oxygen saturation, and temperature, Biogeosciences, 10, 5967-5975, doi:10.5194/bg-10-5967-2013, 2013.

Booth, J. A. T., McPhee-Shaw, E. E., Chua, P., Kingsley, E., Denny, M., Phillips, R., Bograd, S. J., Zeidberg, L. D., and Gilly, W. F.: Natural intrusions of hypoxic, low $\mathrm{pH}$ water into nearshore marine environments on the California coast, Cont. Shelf Res., 45, 108-115, doi:10.1016/j.csr.2012.06.009, 2012.

Boyd, P. W.: Beyond ocean acidification, Nat. Geosci., 4, 273-274, 2011.

Buckley, L. B. and Kingsolver, J. G.: Functional and phylogenetic approaches to forecasting species' responses to climate change, Annu. Rev. Ecol. Evol. Syst., 43, 205-226, doi:10.1146/annurevecolsys-110411-160516, 2012.

Chan, F., Barth, J., Blanchette, C., Chavez, F., Cheriton, O., Friederich, G., gay, Gouhier, T., Hill, T. M., Hofmann, G. E., McManus, M., Menge, B. A., Russell, A. D., Sanford, E., and Washburn, L.: Widespread detection of coastal ocean acidification across the California Current System, in preparation, 2014.

Checkley Jr, D. M. and Barth, J. A.: Patterns and processes in the California Current System, Progr. Oceanogr., 83, 49-64, doi:10.1016/j.pocean.2009.07.028, 2009.

Chown, S. L.: Trait-based approaches to conservation physiology: Forecasting environmental change risks from the bottom up, P. T. Roy. Soc. B, 367, 1615-1627, doi:10.1098/rstb.2011.0422, 2012.

Chown, S. L. and Gaston, K. J.: Macrophysiology for a changing world, Proc. Roy. Soc. B, 275, 1469-1478, 2008.

Costanza, R., d'Arge, R., de Groot, R., Farber, S., Grasso, M., Hannon, B., Limburg, K., Naeem, S., O’Neil, R. V., Paruelo, J., Raskin, R. G., Sutton, P., and van den Belt, M.: The value of the world's ecosystem services and natural capital, Nature, 387, 253-260, 1997.

Crim, R. N., Sunday, J. M., and Harley, C. D. G.: Elevated seawater $\mathrm{CO}_{2}$ concentrations impair larval development and reduce larval survival in endangered northern abalone (Haliotis kamtschatkana), J. Exp. Mar. Biol. Ecol., 400, 272-277, doi:10.1016/j.jembe.2011.02.002, 2011.
Dawson, T. P., Jackson, S. T., House, J. I., Prentice, I. C., and Mace, G. M.: Beyond predictions: Biodiversity conservation in a changing climate, Science, 332, 53-58, doi:10.1126/science.1200303, 2011.

De Wit, P. and Palumbi, S. R.: Transcriptome-wide polymorphisms of red abalone (Haliotis rufescens) reveal patterns of gene flow and local adaptation, Molecul. Ecol., 22, 2884-2897, doi:10.1111/mec.12081, 2012.

Doney, S. C., Fabry, V. J., Feely, R. A., and Kleypas, J. A.: Ocean Acidification: The Other $\mathrm{CO}_{2}$ Problem, Annu. Rev. Mar. Sci., 1, 169-192, 2009.

Dore, J. E., Lukas, R., Sadler, D. W., Church, M. J., and Karl, D. M.: Physical and biogeochemical modulation of ocean acidification in the central North Pacific, P. Natl. Acad. Sci. USA, 106, 1223512240, 2009.

Edmands, S., Moberg, P. E., and Burton, R. S.: Allozyme and mitochondrial DNA evidence of population subdivision in the purple sea urchin Strongylocentrotus purpuratus, Mar. Biol., 126, 443 450, 1996.

Evans, T. G. and Hofmann, G. E.: Defining the limits of physiological plasticity: How gene expression can assess and predict the consequences of ocean change, Philosophical Transactions of the Royal Society B: Biological Sciences, 367, 1733-1745, 10.1098/rstb.2012.0019, 2012.

Evans, T. G., Chan, F., Menge, B. A., and Hofmann, G. E.: Transcriptomic responses to ocean acidification in larval sea urchins from a naturally variable $\mathrm{pH}$ environment, Molecul. Ecol., 22, 1609-1625, doi:10.1111/mec.12188, 2013.

Fassbender, A. J., Sabine, C. L., Feely, R. A., Langdon, C., and Mordy, C. W.: Inorganic carbon dynamics during northern California coastal upwelling, Cont. Shelf Res., 31, 1180-1192, doi:10.1016/j.csr.2011.04.006, 2011.

Feely, R. A., Sabine, C. L., Hernandez-Ayon, J. M., Ianson, D., and Hales, B.: Evidence for upwelling of corrosive "acidified" water onto the continental shelf, Science, 320, 1490-1492, doi:10.1126/science.1155676, 2008.

Feely, R. A., Doney, S. C., and Cooley, S. R.: Ocean acidification: Present conditions and future changes in a high- $\mathrm{CO}_{2}$ world, Oceanography, 22, 37-47, 2009.

Frieder, C. A., Nam, S. H., Martz, T. R., and Levin, L. A.: High temporal and spatial variability of dissolved oxygen and $\mathrm{pH}$ in a nearshore California kelp forest, Biogeosciences, 9, 3917-3930, doi:10.5194/bg-9-3917-2012, 2012.

Gaylord, B., Hill, T. M., Sanford, E., Lenz, E. A., Jacobs, L. A., Sato, K. N., Russell, A. D., and Hettinger, A.: Functional impacts of ocean acidification in an ecologically critical foundation species, J. Exp. Biol., 214, 2586-2594, 2011.

Gillson, L., Dawson, T. P., Jack, S., and McGeoch, M. A.: Accommodating climate change contingencies in conservation strategy, Trends Ecol. Evol., 28, 135-142, doi:10.1016/j.tree.2012.10.008, 2013.

Gouhier, T. C., Guichard, F., and Menge, B. A.: Ecological processes can synchronize marine population dynamics over continental scales, P. Natl. Acad. Sci., 107, 8281-8286, doi:10.1073/pnas.0914588107, 2010.

Gruber, N., Hauri, C., Lachkar, Z., Loher, D., Froelicher, T. L., and Plattner, G.-K.: Rapid progression of ocean acidification in the California Current System, Science, 337, 220-223, doi:10.1126/science.1216773, 2012. 
Hall-Spencer, J. M., Rodolfo-Metalpa, R., Martin, S., Ransome, E., Fine, M., Turner, S. M., Rowley, S., Tedesco, D., and Buia, M.-C.: Volcanic carbon dioxide vents show ecosystem effects of ocean acidification, Nature, 454, 96-99, doi:10.1038/nature07050, 2008.

Harris, K. E., DeGrandpre, M. D., and Hales, B.: Aragonite saturation state dynamics in a coastal upwelling zone, Geophys. Res. Lett., 40, 1-6, 2013.

Harvey, B. P., Gwynn-Jones, D., and Moore, P. J.: Meta-analysis reveals complex marine biological responses to the interactive effects of ocean acidification and warming, Ecol. Evol., 3, 10161030, doi:10.1002/ece3.516, 2013.

Hauri, C., Gruber, N., Plattner, G.-K., Alin, S., Feely, R. A., Hales, B., and Wheeler, P. A.: Ocean acidification in the California Current System, Oceanography, 22, 60-71, 2009.

Hauri, C., Gruber, N., Vogt, M., Doney, S. C., Feely, R. A., Lachkar, Z., Leinweber, A., McDonnell, A. M. P., Munnich, M., and Plattner, G.-K.: Spatiotemporal variability and long-term trends of ocean acidification in the California Current System, Biogeosciences, 10, 193-216, doi:10.5194/bg-10-193-2013, 2013.

Helmuth, B.: From cells to coastlines: How can we use physiology to forecast the impacts of climate change?, J. Exp. Biol., 212, 753-760, 2009.

Hettinger, A., Sanford, E., Hill, T. M., Russell, A. D., Sato, K. N. S., Hoey, J., Forsch, M., Page, H. N., and Gaylord, B.: Persistent carry-over effects of planktonic exposure to ocean acidification in the Olympia oyster, Ecology, 93, 2758-2768, 2012.

Hoffmann, A. A. and Sgrò, C. M.: Climate change and evolutionary adaptation, Nature, 470, 479-485, 2011.

Hofmann, G. E., Smith, J. E., Johnson, K. S., Send, U., Levin, L. A., Micheli, F., Paytan, A., Price, N. N., Peterson, B., Takeshita, Y., Matson, P. G., Crook, E. D., Kroeker, K. J., Gambi, M. C., Rivest, E. B., Frieder, C. A., Yu, P. C., and Martz, T. R.: High-frequency dynamics of ocean $\mathrm{pH}$ : A multi-ecosystem comparison, PLoS ONE, 6, e28983, doi:10.1371/journal.pone.0028983, 2011.

Hofmann, G. E., Blanchette, C. A., Rivest, E. B., and Kapsenberg, L.: Taking the pulse of marine ecosystems: The importance of coupling long-term physical and biological observations in the context of global change biology, Oceanography, 26, 140-148, 2013.

Huey, R. B., Kearney, M. R., Krockenberger, A., Holtum, J. A. M., Jess, M., and Williams, S. E.: Predicting organismal vulnerability to climate warming: Roles of behaviour, physiology and adaptation, P. T. Roy. Soc. B, 367, 1665-1679, 2012.

Ibáñez, I., Gornish, E. S., Buckley, L., Debinski, D. M., Hellmann, J., Helmuth, B., HilleRisLambers, J., Latimer, A. M., MillerRushing, A. J., and Uriarte, M.: Moving forward in globalchange ecology: Capitalizing on natural variability, Ecol. Evol., 3, 170-181, doi:10.1002/ece3.433, 2013.

Jacobs, D. K., Haney, T. A., and Louie, K. D.: Genes, diversity, and geologic process on the pacific coast, Annu. Rev. Earth Planet. S., 32, 601-652, 2004.

Johansen, H. W.: Coralline algae, a first synthesis, CRC Press, Inc., Boca Raton, Florida, 239 pp., 1981.

Kawecki, T. J. and Ebert, D.: Conceptual issues in local adaptation, Ecol. Lett., 7, 1225-1241, 2004.

Kelly, M. W. and Hofmann, G. E.: Adaptation and the physiology of ocean acidification, Funct. Ecol., 27, 980-990, doi:10.1111/j.1365-2435.2012.02061.x, 2012.
Kelly, M. W., Padilla-Gamiño, J. L., and Hofmann, G. E.: Natural variation, and the capacity to adapt to high $p \mathrm{CO}_{2}$ in a keystone species, Glob. Change Biol., 19, 2536-2546, doi:10.1111/gcb.12251, 2013 .

Kelly, R. P., Foley, M. M., Fisher, W. S., Feely, R. A., Halpern, B. S., Waldbusser, G. G., and Caldwell, M. R.: Mitigating local causes of ocean acidification with existing laws, Science, 332, 1036-1037, doi:10.1126/science.1203815, 2011.

Koch, M., Bowes, G., Ross, C., and Zhang, X. H.: Climate change and ocean acidification effects on seagrasses and marine macroalgae, Glob. Change Biol., 19, 103-132, doi:10.1111/j.1365-2486.2012.02791.x, 2013.

Kroeker, K. J., Micheli, F., Gambi, M. C., and Martz, T. R.: Divergent ecosystem responses within a benthic marine community to ocean acidification, P. Natl. Acad. Sci. USA, 108, 14515-14520, doi:10.1073/pnas.1107789108, 2011.

Kroeker, K. J., Kordas, R. L., Crim, R., Hendriks, I. E., Ramajo, L., Singh, G. S., Duarte, C. M., and Gattuso, J.-P.: Impacts of ocean acidification on marine organisms: Quantifying sensitivities and interaction with warming, Glob. Change Biol., 19, 1884-1896, doi:10.1111/gcb.12179, 2013.

LaVigne, M., Hill, T. M., Sanford, E., Gaylord, B., Russell, A. D., Lenz, E. A., Hosfelt, J. D., and Young, M. K.: The elemental composition of purple sea urchin (Strongylocentrotus purpuratus) calcite and potential effects of $p \mathrm{CO}_{2}$ during early life stages, Biogeosciences, 10, 3465-3477, doi:10.5194/bg-10-3465-2013, 2013.

Martz, T. R., Connery, J. G., and Johnson, K. S.: Testing the Honeywell Durafet ${ }^{\circledR}$ for seawater $\mathrm{pH}$ applications, Limnol. Oceanogr.Methods, 8, 172-184, 2010.

Matson, P. G., Yu, P. C., Sewell, M. A., and Hofmann, G. E.: Development under elevated $p \mathrm{CO}_{2}$ conditions does not affect lipid utilization and protein content in early life-history stages of the purple sea urchin, Strongylocentrotus purpuratus, Biol. Bullet., 223, 312-327, 2012.

Menge, B. A. and Menge, D. N. L.: Dynamics of coastal meta-ecosystems: The intermittent upwelling hypothesis and a test in rocky intertidal regions, Ecol. Monogr., 83, 283-310, doi:10.1890/12-1706.1, 2013.

Menge, B. A., Chan, F., and Lubchenco, J.: Response of a rocky intertidal ecosystem engineer and community dominant to climate change, Ecol. Lett., 11, 151-162, 2008.

Miklasz, K. A.: Physical constraints on the size and shape of microalgae, Stanford University, 268 pp., 2012.

Navarrete, S. A., Broitman, B. R., and Menge, B. A.: Interhemispheric comparison of recruitment to intertidal communities: Pattern persistence and scales of variation, Ecology, 89, 1308-1322, doi:10.1890/07-0728.1, 2008.

O’Donnell, M. J., Hammond, L. M., and Hofmann, G. E.: Predicted impact of ocean acidification on a marine invertebrate: Elevated $\mathrm{CO}_{2}$ alters response to thermal stress in sea urchin larvae, Mar. Biol., 156, 439-446, 2009.

O’Donnell, M. J., Todgham, A. E., Sewell, M. A., Hammond, L. M., Ruggiero, K., Fangue, N. A., Zippay, M. L., and Hofmann, G. E.: Ocean acidification alters skeletogenesis and gene expression in larval sea urchins, Mar. Ecol.-Prog. Ser., 398, 157-171, doi:10.3354/meps08346, 2010. 
O'Donnell, M. J., George, M. N., and Carrington, E.: Mussel byssus attachment weakened by ocean acidification, Nat. Clim. Change, 3, 587-590, 2013.

Orr, J. C., Fabry, V. J., Aumont, O., Bopp, L., Doney, S. C., Feely, R. A., Gnanadesikan, A., Gruber, N., Ishida, A., Joos, F., Key, R. M., Lindsay, K., Maier-Reimer, E., Matear, R., Monfray, P., Mouchet, A., Najjar, R. G., Plattner, G.-K., Rodgers, K. B., Sabine, C. L., Sarmiento, J. L., Schlitzer, R., Slater, R. D., Totterdell, I. J., Weirig, M.-F., Yamanaka, Y., and Yool, A.: Anthropogenic ocean acidification over the twenty-first century and its impact on calcifying organisms, Nature, 437, 681-686, 2005.

Padilla-Gamiño, J. L., Kelly, M. W., Evans, T. G., and Hofmann, G. E.: Temperature and $\mathrm{CO}_{2}$ additively regulate physiology, morphology and genomic responses of larval sea urchins, Strongylocentrotus purpuratus, Proc. R. Soc. B, 280, 1759, 20130155, doi:10.1098/rspb.2013.0155, 2013.

Pespeni, M. H., Garfield, D. A., Manier, M. K., and Palumbi, S. R.: Genome-wide polymorphisms show unexpected targets of natural selection, P. Roy. Soc. B, 279, 1412-1420, doi:10.1098/rspb.2011.1823, 2012.

Pespeni, M. H., Sanford, E., Gaylord, B., Hill, T. M., Hosfelt, J. D., Jaris, H. K., LaVigne, M., Lenz, E. A., Russell, A. D., Young, M. K., and Palumbi, S. R.: Evolutionary change during experimental ocean acidification, Proc. Natl. Acad. Sci. USA, 110, 6937-6942, doi:10.1073/pnas.1220673110, 2013a.

Pespeni, M. H., Barney, B. T., and Palumbi, S. R.: Differences in the regulation of growth and biomineralization genes revealed through long-term common-garden acclimation and experimental genomics in the purple sea urchin, Evolution, 67, 1901-1914, doi:10.1111/evo.12036, 2013b.

Pespeni, M. H., Chan, F., Menge, B. A., and Palumbi, S. R.: Signs of adaptation to local $\mathrm{pH}$ conditions across an environmental mosaic in the California Current Ecosystem, Integr. Comp. Biol., 53, 857-870, 2013c.

Pettorelli, N.: Climate change as a main driver of ecological research, J. Appl. Ecol., 49, 542-545, doi:10.1111/j.13652664.2012.02146.x, 2012.

Pickett, S. T. A.: Space-for-time subsitution as an alternative to long-term studies, in: Long-term studies in ecology: Approaches and alternatives, edited by: Likens, G. E., Springer-Verlag, New York, 110-135, 1989.

Price, N. N., Martz, T. R., Brainard, R. E., and Smith, J. E.: Diel variability in seawater $\mathrm{pH}$ relates to calcification and benthic community structure on coral reefs, PLoS ONE, 7, e43843, doi:10.1371/journal.pone.0043843, 2012.

Provoost, P., van Heuven, S., Soetaert, K., Laane, R. W. P. M., and Middelburg, J. J.: Seasonal and long-term changes in $\mathrm{pH}$ in the Dutch coastal zone, Biogeosciences, 7, 3869-3878, doi:10.5194/bg-7-3869-2010, 2010.

Sanford, E. and Kelly, M. W.: Local adaptation in marine invertebrates, Annu. Rev. Mar. Sci., 3, 509-535, doi:10.1146/annurevmarine-120709-142756, 2011.
Santana-Casiano, J. M., Gonzalez-Davila, M., Rueda, M. J., Llinas, O. J., and Gonzalez-Davila, E. F.: The interannual variability of oceanic $\mathrm{CO}_{2}$ parameters in the northeast Atlantic subtropical gyre at the ESTOC site, Global Biogeochem. Cy., 21, GB1015, doi:10.1029/2006GB002788, 2007.

Sunday, J. M., Calosi, P., Dupont, S., Munday, P. L., Stillman, J. H., and Reusch, T. B. H.: Evolution in an acidifying ocean, Trends Ecol. Evol., doi:10.1016/j.tree.2013.11.001, 2013.

Steinberg, D. K., Martinson, D. G., and Costa, D. P.: Two decades of pelagic ecology in the Western Antarctic Peninsula, Oceanography, 25, 56-67, 2012.

Sunday, J. M., Crim, R. N., Harley, C. D. G., and Hart, M. W.: Quantifying rates of evolutionary adaptation in response to ocean acidification, PLoS ONE, 6, e22881, doi:10.1371/journal.pone.0022881, 2011.

Tatters, A. O., Fu, F. X., and Hutchins, D. A.: High $\mathrm{CO}_{2}$ and silicate limitation synergistically increase the toxicity of Pseudonitzschia fraudulenta, PLoS ONE, 7, e32116, doi:10.1371/journal.pone.0032116, 2012.

Thomsen, J., Casties, I., Pansch, C., Körtzinger, A., and Melzner, F.: Food availability outweighs ocean acidification effects in juvenile Mytilus edulis: Laboratory and field experiments, Glob. Change Biol., 19, 1017-1027, 10.1111/gcb.12109, 2013.

Visser, M. E.: Keeping up with a warming world; assessing the rate of adaptation to climate change, P. Roy. Soc. B, 275, 649-659, 2008.

Washburn, L., Fewings, M. R., Melton, C., and Gotschalk, C.: The propagating response of coastal circulation due to wind relaxations along the central California coast, J. Geophys. Res.Oceans, 116, C12028, doi:10.1029/2011JC007502, 2011.

Wernberg, T., Smale, D. A., Tuya, F., Thomsen, M. S., Langlois, T. J., de Bettignies, T., Bennett, S., and Rousseaux, C. S.: An extreme climatic event alters marine ecosystem structure in a global biodiversity hotspot, Nat. Clim. Change, 3, 78-82, 2013.

Williams, S. E., Shoo, L. P., Isaac, J. L., Hoffmann, A. A., and Langham, G.: Towards an integrated framework for assessing the vulnerability of species to climate change, PLoS Biol., 6, e325, doi:10.1371/journal.pbio.0060325, 2008.

Wootton, J. T. and Pfister, C. A.: Carbon system measurements and potential climatic drivers at a site of rapidly declining ocean pH, PLoS ONE, 7, e53396, doi:10.1371/journal.pone.0053396, 2012.

Wootton, J. T., Pfister, C. A., and Forester, J. D.: Dynamic patterns and ecological impacts of declining ocean $\mathrm{pH}$ in a highresolution multi-year dataset, P. Natl. Acad. Sci., 105, 1884818853, 2008

Yu, P. C., Matson, P. G., Martz, T. R., and Hofmann, G. E.: The ocean acidification seascape and its relationship to the performance of calcifying marine invertebrates: Laboratory experiments on the development of urchin larvae framed by environmentally-relevant $p \mathrm{CO}_{2} / \mathrm{pH}$, J. Exp. Marine Biol. Ecol., 400, 288-295, doi:10.1016/j.jembe.2011.02.016, 2011. 